$1 \mathrm{~F}-06$

人体計湘データベース構築（第 2 報）

ーデータの収集方法についてー

○高橋真佐美、加藤まや、生沢佳弘、杉山康夫、栗山洋四（人間生活工学研究センター）

Towards the construction of a database for human body shape (2)

Research institute of human engineering for quality life

Masami Takahasi, Maya Kato, Yosihiro Ikuzawa, Yasuo Sugiyama, \& Hirosi Kuriyama

1.はじめに

人体計測データベースの構築に不可欠な計 测方法、計测項目について報告する。今回の 人体計测データベースは登録人数、計测項目 等過去に類を見ないものである。本編では今 回計測するに至った数多くの計測項目の詳細 及び、短時間で出来る限り多くのデータを収 集するために開発された計測方法について報 告する。

\section{2. 計测項目}

計測項目は、社団内に組織された学識経験 者で構成される計測対象ワーキンググルーブ （WG）での意見をもとに決定した。まず J I S 及びI S Oの項目を最小限の基準とした 上で、約 300 項目を挙げ、従来のようにア パレル関係だけでなく、家電、建設、住宅、 自動車、化学、特殊器具等のあらゆる分野の 主要 35 社からのニーズを集めた。W Gによ り被計测者、計测者の負担や 3 次 元計测機の能力、ニーズの必要性 等を検討し、多くの項目を絞り込 んだ結果、以下に説明する 3 種類 の計測とそれらの計測項目から計 算で求めるるのを合わせた 178 項目を今回の計测項目としている。 左右対象な部分については、I S ○が今後左側を計测するであろう という最新情報を基に、左側を計 湘することにW Gで決定した。人
体の部分による内訳は、体幹115 項目、手 39 項目、顔 24 項目である。

\section{3. 計测方法}

バス内配置図を図1に示す。計测はバス内 で非接触三次元計测機による画像計測、スラ イディングスケールによる計测、手計測のそ れぞれの計测が流れ作業で行われる。 (1)三次元計測機

図 2 に测定原理を示す。照明・撮像系の構 成はよく知られている光切断法の構成と同じ であり、測定対象の斜め上方からスリット光 を測定対象の表面全体にわたって回転走查し、 これを直上からテレビカメラで撮像する。実 際の装置では測定精度を保証する為に形状演 算にあたって、テレビカメラのパースペクテ ィブ歪の補正を行い、さらに测定の死角を少 なくする為に测定対象を左右両側から走查し、 得られる形状データの有効領域同士を貼り合 
わせて最終的な形状データとしている。上記 の測定原理に基づき、顔・手用と体幹用の 2 種類の人体形状計測装置を製作し、計測車に 組み込んでいる。顔の測定例を図 3 に示す。 計測項目は 86 項目。ここで得られた画像デ 一タは、白黒（256 諧調）で表現されたビ ジュアルデータである輝度データと、形状を 表す X、Y、Zの座標データである高さデー タの 2 種類で構成されており、ビジュアル表 示されたデータから特徵点抽出を行い、今回 の計测項目以外にも、必要亡される人体のさ まざまな直線距離、曲線距離を测定すること がをことが可能である。

(2)スライディング・スケール

スライディング・スケールは、体幹を触診 しなければ正確な計測ができない部位や、適 当な压をかけて計る必要がある部位を、パソ

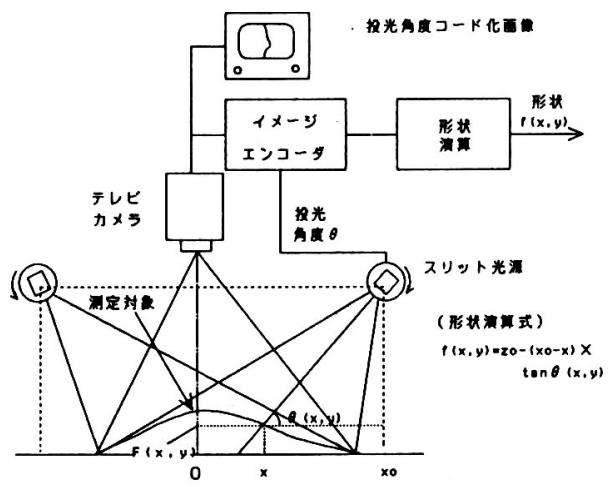

図 2 測定原理

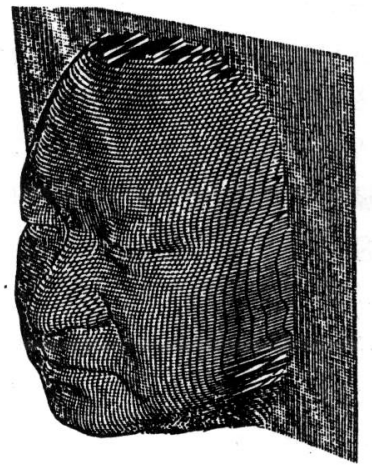

困 3 顔の湘定例
コンを介したリンクアームとプレートで接触 させて計测し、計測結果をデータディスクに 収録するシステムである。計测項目は 12 項 目。

(3)手計测

三次元計測器による計測が不向きな項目の 計测をの 7 種類のマルチン計測器等による直 接計测を行っている。計测項目は 65 項目。 計测者と記録者の二人一組で行う。

\section{5.まとめ}

今回、非接触 3 次元計测器やスライディン グゲージというコンピュータを用いての計測 方法を取り入れることで多数の項目を計測す ることが可能となった。今後、今回手計測で 測っている項目を、三次元画像データから推 定することができれば、被計測者、計测者双 方の負担を一層軽減することができ、さらに 今回の計測項目以外のデータを得る事す可能 となるであろう。

\section{謝辞}

今回の人体計測を行うにあたり、計測対象 - 計測技術・計測作業の各W Gの委員各位に 絶大なるご支援を睗りました。わけても計测 部位とその定義（計測基準）の決定は、芦澤 玫美教授（大妻女子大）、谷井克則博士（生 命工学研）に負うすのです。また全国の大学 の先生方に御協力いただくために山名信子教 授（京都女子大）に御奔走いただきました。 それぞれの方に謝意を表します。

\section{参考文献}

1）上杉、猪股：映像情報 (1989/12)

2) 上杉：’92 センシング技術応用 セミナー資料 (1992) 